\title{
A LITERATURE REVIEW ON FINANCIAL LITERACY
}

\author{
Selim AREN* \\ Sibel DİNÇ AYDEMİR**
}

\begin{abstract}
Based on prior research, this paper provides insights regarding financial literacy. Amidst this research, some similarities and contrarinesses have been manifested by juxtaposing this literature in terms of (1) definitional issues on financial literacy, (2) its probable endegoeneity, (3) its determinants and consequences established by the extant research, (4)other probable estimators of financial decision making which would individually make differences aside from financial literacy, (5)manner of measuring it (i.e., subjectiveobjective measures versus proxies, (6) targeted population for finding evidence. This study indicates that (i) there is a need of a common and well-structured definition of financial literacy due to the interchangeably usage of various concepts, all of which mean the financial knowledge level of individual, (ii) objective measures seem to work best in measuring financial literacy among individuals, (iii) researchers should reconsider about proxies for financial literacy in the event that individual effect of proxy may be difficult to be seperated, (iv) it is better to consider that financial literacy may be potentially endogenous variable rather than the exogenous one, (v) studies should present an explicit explanation how the relationship between financial literacy and research problem (e.g., investment preferences) occurred, (vi) relative impact of financial literacy should be preemptively examined by incorporating other potential factors influencing financial decision making into research models.
\end{abstract}

Keywords: Financial literacy, financial behavior, subjective-objective financial literacy measures.

Jel Codes: G0, G10, G11.

\section{FINANSAL OKURYAZARLIK ÜZERİNE LITTERATÜR İNCELEMESİ \\ Öz}

$\mathrm{Bu}$ çalışma, önceki araştırmaları temel alarak, finansal okuryazarlığa ilişkin içgörü kazandırmayı amaçlamaktadır. Finansal okuryazarlığa dönük tanımsal meseleler, finansal okuryazarlığın olası içselliği,

* Doç. Dr., Gebze Yüksek Teknoloji Enstitüsü, aren@gyte.edu.tr.

** Doktora Öğrencisi, Gebze Yüksek Teknoloji Enstitüsü, saydemir@gyte.edu.tr. 
mevcut literatürde ortaya çıkarılmış öncülleri ve sonculları, finansal okuryazarlıktan başka finansal karar vermede bireysel farklılık yaratabilecek diğer tahmin ediciler, finansal okuryazarlığı ölçme biçimi, hedeflenen anakütle bağlamlarında literatürün yan yana getirilmesi suretiyle bu araştırmalar arasında bazı benzerlik ve farklılıklar ortaya konmuştur. Bu çalışma (i) ortak ve iyi yapılmış bir bir finansal okuryazarlık tanımlamasına ihtiyaç olduğuna, (ii) objektif ölçeklerin bireyler arasındaki finansal okuryazarlığı ölçmede daha iyi olabileceğine, (iii) finansal okuryazarlık yerine geçebilecek değişkenleri kullanmadan önce, sözkonusu değişkenin bireysel etkisi ile finansal okuryazarlık etkisini birbirinden ayırmanın zorluğu üzerine araştırmacıların yeniden düşünmelerine, (iv) finansal okuryazarlığın dişsal bir değişken olmaktan öte mümkün bir içsel değişken olabileceğine, (v) çalışmaların finansal okuryazarlık ile araştırma problemi arasındaki ilişkinin nasıl ortaya çıktığına yönelik açılamayı içermesine, (vi) araştırma modellerine finansal karar vermeyi etkileyen diğer olası değişkenlerin dâhil edilmesi suretiyle finansal okuryazarlığın görece etkisinin öncelikle değerlendirilmesine işaret etmektedir.

Anahtar Kelimeler: Finansal okuryazarlık, finansal davranış, subjektif-objektif finansal okuryazarlık ölçekleri.

Jel Kodları: G02, G10, G11.

\section{Introduction}

Financial literacy has ever-increasing importance in our day. Especially in economic and financial domains, whether people are financially knowledgeable helps greatly in explaining various financial or economic behavior. Decision makings of economic agents are highly shaped by their financial literacy regarding understanding fundamental financial topics. In the course of time, individuals have increasingly been more active agents who are responsible for their financial planning than even before. In fact, this increased responsibility fundamentally could have stemmed from an humanistic need- preserving self, since recent crises predominantly damaged the naive and the inexperienced. In one hand, global crisis, known as subprime mortgage crisis in 2008, can be said to bring financial comprehension into the forefront (Mandell and Klein, 2009, p. 16; Robb and Woodyard, 2011, p. 60; Shahrabani, 2012, p. 156). On the other hand, the two main issues may contribute to this financial comprehension's importance (Rooij, Lusardi and Alessi, 2007, p.2). First, the diversity of financial products, many of which are rather complicated and inapprehensible necessiates knowing and understanding financial concepts and matters. Mandell and Klein (2009, p.16) states that this variety of financial products in US has been come along after the advent of financial markets deregulation. Second, last social security change in US, in fact all over the world, requires individuals to actively act in their financial management. One way or another, understanding financial concepts and recognizing financial instruments seems substantially essential for individual's all financial decisions.

Akerlof and Schiller (2010, pp.147-162) in their book of "Spiritus Animalis" argue the saving problem in that many people, on average, do not save enough and this problem could direct them to remain unprotected in their old age at that time they could no more money and their 
consumption could exceed their income. However put mainly emphasis on cultural differences in savings, they also refer to the power of compound interest and to their students' unawareness of this power.

Moreover, there have been some studies revealing that financial knowledge made a difference in investment risk perceptions. More specifically, Diacon (2004, p.187) detected significant differences between financial experts and lay people who have less financial knowledge compared to financial experts. Accordingly, lay people tended to have more risk averse than financial experts and to expose to affiliation bias (i.e., finding suppliers and salesman more credible than lay people). Also, these people viewed as having less financial knowledge think more likely that financial products are too complicated. In another study (Wang, Keller \&Siegrist, 2011, p.11), authors conducting a risk perceptions survey in Switzerland highly correlate knowledge-related scales with risk-related scales. And they conclude that the participants viewed some investment products more understandable perceived the same products less risky. Therefore, financial literacy would make greater difference in financial settings than it is thought.

Nevertheless, there is a large and growing body of literature revealing that individuals have the deficiency of financial literacy which would assist them to make wise financial decisions (e.g., Guiso and Jappelli, 2008, pp. 1-36; Al-Tamimi and Bin Kalli, 2009, pp. 500-516; Shahrabani, 2012, pp. 156-163). In a study conducted by OECD in 14 countries, Atkinson and Messy (2012, p.7) concludes that financial illiteracy is prevalent in many countries (e.g., Albenia, Poland, Malaysia, UK, South Africa). It seems that people around the world suffer from the lack of financial knowledge no matter in which country they live-developed or not. Beside, recent evidence displays that being unable to understand financial topics may be the underlying reason of portfolio underdiversification (Guiso and Jappelli, 2008, pp. 1-36), lower stock participation (Van Rooij, Lusardi and Alessi, 2007, pp. 1-46), unpreparedness for post-retirement times (Lusardi and Mitchell, 2007b, pp. 35-44), wealth unaccumulation (Van Rooij, Alessi and Lusardi, 2012, pp. 449-478), etc. Although the existence of a considerable and valuable prior research describing the role of financial literacy on financial behavior, little effort has been exerted to explain in which way financial literacy may influence financial behavior. Beside, this studies- however manifested in some- while investigating the effect of financial literacy on any financial behavior or outcome have not included any other explaining variable. Limited studies have examined several variables other than financial literacy such as risk aversion (Van Rooij et al., 2011, p.23), self-regulation, future orientation (Howlett, Kees and Kemp, 2008, pp.227-230), risk tolerance (Van Rooij, Kool and Prast, 2007, p.705), negative emotions, past behaviors and attitudes (Shahrabani, 2012, pp. 157-158), role of self-perception (i.e., internal versus external locus of control) (Perry and Morris, 2005, p.300), trust (Lachance and Tang, 2012, p.213). A great majority of studies regressing a tough and complicate financial decision making or intricate financial behavior on merely financial literacy estimator implys that relevant literature requires to be expanded for more thoroughly comprehension of this complex and uneasy processes.

In this regard, this study juxtaposes and reviews a great number of studies concentrating on financial literacy. Evaluating and discussing their similarities and discrepancies, this study 
implicates that relevant literature needs (i) conceptualizing financial literacy and hence developing a common and parsimonious construct, (ii) building models in which financial literacy would be endogenous as well as exogenous, (iii) including variables such as risk aversiness, time preference that could probably influence a financial decision made commonly under uncertainty, (iv) using objective assessment measures rather than subjective or self-assessed ones in case that overconfidence or underconfidence bias intervene in the suggested connections, (v) not opting for proxies (e.g., demographics) due to the difficulty of disentangling proxy's effect from financial literacy's, (vi) contemplating on the nexus of causality.

Succeeding sections of the paper will be in following way. Firstly, the relevant literature will be reviewed and discussed by some particular distinctions in terms of (i)defining financial literacy, (ii) research domain, (iii) measuring financial literacy with objective-subjective measures or proxies, (iv)targeted population (e.g., general versus specific), (vi) other explanatory variables beyond financial literacy, (vii) findings of financial literacy literature (e.g., determinants versus consequences). Ultimately, based upon a thorough literature review, some considerable inferences and syntheses will be made.

\section{Defining Financial Literacy}

In social sciences, it is indispensable to define an abstract concept to be able to operationalize or to measure it. Yet, it seems that large body of financial literacy literature has been lacking in defining financial literacy (Huston,2010). Indeed, there are limited number of studies giving an exact definition.

Lusardi and Mitchell (2007b, p.36) used the definition of OECD (2005). Accordingly, financial education is defined as "the process by which financial consumers/investors improve their understanding of financial products and concepts, and through information, instruction, and/ or objective advice, develop the skills and confidence to become more aware of financial risks and opportunities to make informed choices, to know where to go for help, and to take other effective actions to improve their financial well-being". Servon and Kaestner (2008, p.273) defines financial literacy as "a person's ability to understand and make use of financial concepts".

According to Huston (2010, p.306), financial literacy such as health or general literacy might be conceptualized with two main dimension: understanding personal finance knowledge and using it. Hence, it could be described as "measuring how well an individual can understand and use personal finance-related information". It is also added that this description is coherent not only with other literacy concepts but also with definitions in the extant financial literature.

On the other hand, it would be better to remunerate some prior research. Albeit the absence of an exact or explicit definition, few authors have identified this concept with its important aspects. To exemplify, Wachira and Kihiu (2012, p.42) states that financial literacy helps consumers in being prepared for difficult times by determining risk mitigant strategies, and in using financial products effectively, most importantly in making plausible decisions. Also, in other study, becoming financially literate refers to possessing knowledge and craft in order to handle money well (Howlett, Kees and Kemp, 2008, p.231). 
Meanwhile, in financial literacy studies, it can be largely seen that financial literacy is interchangeably termed with financial education, financial knowledge or financial sophistication in the literature (e.g., Howlett, Kees and Kemp, 2008, pp.223-242; Al-Tamimi and Bin Kalli, 2009, pp.500-516; Smith, Finke and Huston, 2011, pp.3-15; Yoong, See and Baronowich, 2012, pp. 75-86). Here, it necessiates to clarify one issue. Researchers should behave cautiously to the term "financial education". Some studies, indeed, does not mean financial literacy with the term "financial education". More specifically, Bayer, Bernheim and Scholz (1996, pp. 1-29) examine a retirement seminar's possible impact on financial decision makings with the title of "The Effects of Financial Education ........ Similarly, profounding that uncertain effect of financial education on succeeding financial behavior in the extant literature, Mandell and Klein (2009, pp. 15-24) explores the influence of a particular financial course on subsequent financial behavior. Although it must be careful to make inference from results due to the very small sample size in this study, the aim of this exemplification here is to warn researchers not to cause any misunderstandings. In other words, however substituting for financial literacy at times, financial education in some authors' studies may really refer to "financial education".

\section{Juxtaposing Financial Literacy Literature}

While emphasising on the impact of financial literacy, researchers approach this phenomenon from different points of view. In other words, academicians taps into financial literacy to be able to explain economic well being, financial decision making and behavior, and rarely corporate governance and social well-being.

From the view of economic well-being, numerous studies attempts to explain the relationship between financial literacy and economic wealth accumulation. In explaining this relationship, several academicians call attention to financial or more specifically retirement planning (Lusardi and Mitchell, 2007a, pp. 205-224; Howlett, Kees and Kemp, 2008, pp.223-242; Yoong, See and Baronovich, 2012, pp. 75-86; Van Rooij, Lusardi and Alessi, 2011, pp. 1-40) while others refer to stock market participation (Van Rooij et al., 2007, pp. 1-46) or both (Van Rooij et al., 2012, pp. 449-478).

In terms of financial domain, a considerable amount of literature has been concentrated on financial literacy. While some studies determine the level of financial literacy among particular groups (e.g., Ansong and Gyensare, 2012, pp. 126-133; Lusardi, Mitchelle and Curto, 2010, pp. 358-380; Chen and Volpe, 1998, pp. 107-128;), a vast number of research investigates the possible effect of financial literacy on several financial decision and behavior (e.g., Bayer, Bernheim and Scholz, 1996, pp. 1-29; Hilgert, Hogarth and Beverly, 2003, pp. 309-322; Dhar and Zhu, 2006, pp. 726-740; Servon and Kaestner, 2008, pp. 271-305; Guiso and Jappelli, 2008, pp. 1-36; Van Rooij, Lusardi and Alessi, 2007, pp.1-46; Dvorak and Hanley, 2010, PP. 645-652; Lusardi and Mitchell, 2007a, pp. 205-224;Al-Tamimi and Bin Kalli, 2009, pp. 500-516; Shahrabani, 2012, pp. 156-163; Mandell and Klein, 2009, pp. 15-24; Müller and Weber, 2010, pp. 126-153; Smith, Finke and Huston, 2011, pp. 3-15; Van Rooij, Lusardi and Alessi, 2011, pp. 1-40; Cole, Sampson and Zia, 2011, pp. 1933-1967; Perry and Morris, 2005, pp. 299-313; Ludlum et al., 2012, pp. 25-33; Robb 
and Woodyard, 2011, pp. 60-70; Robb, 2011, pp. 690-698;Wachira and Kihiu, 2012, pp. 42-50; Lachanse and Tang, 2012, pp. 209-226).

Differed admiringly, there are few number of studies discussing people's financial literacy from the viewpoint of corporate governance (McDaniel, Martin and Maines, 2002, pp. 139-167) and social well-being (Kindle, 2010, pp. 470-481). McDaniel, Martin and Maines (2002, p.139) concludes that there are significant differences between financial experts and financial literates in auditing committees in terms of assessing the quality of financial reporting. In this regard, inclusion of financial expertise in auditing committee may have influence on committee's total evaluation of corporation's financial report by shifting both the framework and also focal of committee's arguments.

As for Kindle (2010, p.472), this study manifests the relation of becoming financially unlucky to sociall well-being by suggesting a connection between being psychologically uneasy and unfavorable financial events such as financial stress, overdebtedness. Hence, the study aims to measure social work students' awareness of whether financial literacy is relevant to their future implementations since they are potential social workers of the future. These students reported that financial knowledge is found to be highly relevant for some problems such as poverty.

Additionally, Vass (2012, p.174) argues whether monetary and financial issues could be deemed a way of representing and reflecting both the form and also the future orientation of couples, instead of considering them only being results of whether people are financially knowledgeable. Thus, the study proclaims that financial literacy programs neglect this aspect.

\section{Measuring Financial Literacy}

\section{I. Data Collection Method}

In extant literature, financial literacy generally has been measured in three ways. Accordingly, there exist four strands of literature.First strand of literature (e.g., Chen and Volpe, 1998, pp. 107-128; Hilgert, Hogarth and Beverly, 2003, pp. 309-322; Lusardi, Mitchell, and Curto, 2010, pp. 358-380; Cole, Sampson and Zia, 2011, pp. 1933-1967; Van Rooij, Lusardi, and Alessi, 2011, PP. 1-40; Dvorak and Hanley, 2010, pp.645-652; Lusardi and Mitchell, 2007a, pp. 205-224; Howlett, Kees and Kemp, 2008, pp. 223-242;Al-Tamimi and Bin Kalli, 2009, pp. 500-516; Ansong and Gyensare, 2012, pp. 126-133; Shahrabani, 2012, pp. 156-163;Yoong, See and Baronovich, 2012, pp. 75-86; Robb, 2011, pp. 690-698) exploits objective financial literacy scales in measuring at which level people' financial knowledge are. Accordingly, some basic and advanced financial questions are asked to targeted population and then responses are evaluated according to their accuracy. When carefully examined, one point in these objective financial literacy tests attracts the attention. Objective measures of financial literacy have varied according to the extent of which questions were asked to respondents. To exemplify, Chen and Volpe (1998, p.113) asked 36 multiple-choice questions to the participants to measure their financial knowledge while Van Rooij, Lusardi and Alessi (2011, pp.605-606) utilized a financial literacy module consisting of 16 true-false (also including "don't know" option) questions. As a matter of course, the number of questions may have 
varied according to the research design but this scale variation still constitute an impediment for replication studies. Hence, it can be said that the extant literature needs a common and universal measurement scale in order to operationalize the financial literacy of individuals.

Second strand of literature (e.g., Van Rooij, Koll and Prast, 2007, pp. 701-722; Perry and Morris, 2005, pp. 299-313) attempts to measure financial literacy by assessing perceptions of targeted population. Namely, participants are asked to evaluate their financial knowledge themselves according to a scale ranging between particular values (e.g., five-point likert scale).

Third body of literature (e.g., Guiso and Jappelli, 2008, pp. 1-36; Van Rooij, Lusardi and Alessi, 2007, pp. 1-46; Robb and Woodyard, 2011, pp. 60-70; Müller and Weber, 2010, pp. 126153) identifies financial literacy level of participants with both objective or test based and also subjective or self-assessed measures.

Apart from those mentioned above, fourth body of literature, however limited, employs proxies for measuring financial literacy on the ground that a lot of studies have concluded that these factors chosen as proxies strongly correlate with financial literacy. Specifically, the study of Dhar and Zhu (2006) aims to explore the association between investor literacy and disposition effect and provides evidence of that higher financial knowledge represented by particular demographics relates to lower disposition effect (p.738). More clearly, investors with higher income and those working in professional careers tend to experience lower disposition effect. At this point, it should be mentioned that this study taps into wealth, occupation, gender and age in order to substitute for financial literacy. Yet, in a study (Müller and Weber, 2010, p. 134) which regress financial literacy on demographic and socioeconomic variables in order to evaluate their proximity for financial literacy, it is found that these variables are not good proxies for financial literacy with the poor explanation power.

On the other hand, using proxies for any variable may accommodate an important disadvantage. An example would work best here. When authors utilize a proxy, let's say income, substituting for financial literacy, it could be very difficult to discern the individual effect of financial literacy from the independent effect of income variable. Researchers should consider this nonignorable disadvantage while intending to choose proxies in their research design.

\subsection{Sample}

Studies drawing attention to financial literacy to explain underlying variable (e.g., financial decision making or behavior and economic well-being) can be categorized into two groups in regard to their sample which is considered to be representative of targeted population. Some research concentrated on general groups while others focused on specific groups. In terms of general population, most studies aimed at households and people in a particular country (e.g., Lusardi and Mitchell, 2007b, pp.35-44; Hilgert, Hogarth and Beverly, 2003, pp. 309-322; Van Rooij, Lusardi and Alessi, 2011, pp. 1-40; Yoong, See and Baronovich, 2012, pp. 75-86; Wachira and Kihiu, 2012, pp. 42-50; Cole, Sampson and Zia, 2011, pp. 1933-1967). Much research targeted on general sample has tapped into national surveys. According to Dvorak and Hanley (2010, p.645), studies exploiting national surveys have an advantage over other studies since national surveys 
provided large samples for researchers, enabling them to make more generalizable inferences from their studies. However, these studies have come short of explaining logical connections between financial literacy and financial decisions.

In terms of specific groups, these studies investigates the problem on women (Lusardi and Mitchell, 2008, pp. 1-10), employees (Bayer, Bernheim and Scholz, 1996, pp. 1-29; Van Rooij, Kool, and Prast, 2007, pp. 701-722), bank clients (Guiso and Jappelli, 2008, pp. 1-36), investors (Dhar and Zhu, 2006, pp. 726-740; Al-Tamimi, Bin Kalli, 2009, pp. 500-516; Müller and Weber, 2010, pp. 126-153), auit committees (McDaniel, Martin adn Maines, 2002, pp. 139-167), working students (Ansong and Gyensare, 2012, pp. 126-133), college students (Chen, and Volpe, 1998, pp. 107-128; Robb, 2011, pp. 690-698; Shahrabani, 2012, pp. 156-163; Ludlum et al., 2012, pp. 25-33), people who took a particular financial course (Mandell and Klein, 2009, pp. 15-24), consumers (Perry and Morris, 2005, pp. 299-313), financial professionals (Lachance and Tang, 2012, pp. 209-226), baby boomers (Lusardi and Mitchell, Oct. 2006, pp.1-39), the young (Lusardi, Mitchell, Curto, 2010, pp. 358-380), lower-incomed bank customers (Servon adn Kaestner, 2008, pp. 271305), and social work students (Kindle, 2010, pp. 470-481).

These studies targeted on specific samples such as women, students, employers have been erudite in the manner that their research provides beneficial insight into policy making. By this means, policy makers which especially targeted on alleviating the problem of particular parts in society (e.g., young, women, old people) could take these inferences into their accounts since it is not desirable that this established illiteracy would afflict these specific groups. Hence, the research focused on these specific groups may highlight some implications which could be crucial cues for policy makers' agenda.

\subsection{Other Explanatory Variables Excluding Financial Literacy}

It has been argued in some studies that risk averseness may somewhat predict individual differences in economic or financial decisions (Rooij, Lusardi and Alessi; 2007, p.23) since people display divergency between their attitude to risk taking. This divergency may reflect on their finance-related behaviors. Hence, it is suggested that risk averseness together with financial literacy be included to the research model arguing the occurrence of any financial decision making. Through risk averseness, it is possible to evaluate financial literacy's relative impact. Or, after controlling for risk averseness effect, it must be tested whether financial literacy still remains a significant agent in explaining the relevant behavior.

At this point, several studies have employed the risk averseness variable in order to explain individual differences in financial behavior. Guiso and Jappelli (2008, p.13), after controlling for risk aversion variable, provides evidence of financial literacy as a significant determinant in explaining portfolio underdiversification. Anorther study concludes that risk tolerance is the most influent factor in pension matters. Study participants assess themselves as highly both risk averse and also financially illiterate (Van Rooij, Kool and Prast, 2007, p. 719).

Similar to risk averseness, time preferences defined as the extent to which people discount the future may have impact on financial behavior. Whether people heavily choose today to 
future or vice versa may have impact on financial behavior especially such as long run financial planning (i.e., retirement planning). With this rationale, Lusardi, Mitchell and Curto (2010, p.362) hypothesized that people who prefer today than future may have less tendency to attain financial knowledge which takes a long time, also suggesting that time preference may influence on financial literacy. Yet, they employed smoking activities to represent people's time preference. In this manner, some research propounds that people's future orientation and self-regulatory state identically can affect the financially related behavior. Howlett, Kees and Kemp (2008, pp. 227232) build a model proposing that self-regulatory state, future orientation and financial literacy wholely may explain retirement planning. Self-regulatory state which can be thought as a period in which people exert control on their beliefs and thoughts may activate on choices going a long way which people make. Future orientation, just like time preference, refers to the way which people weight time. Accordingly, people may exhibit divergencies between thinking about the short or long term outcomes of their behaviors. The study finds that not only financial literacy but also future orientation moderated by self-regulatory state have importance on financial decision making. Compared to other related studies, Howlett, Kees and Kemp's (2008) study can be said to have a place in the extant literature in the manner utilizing other variables which both could lead to individual differences and also could influence financial variables.

As a third variable in explaining financial behavior together with financial literacy, the academicians have utilized overconfidence variable which is known as the state of that people think that they know more than they actually do while regressing the financial behavior. We should make a distinction here. First, some research has measured financial literacy by utilizing both objective and self-assessed tests (e.g., Van Rooij, Lusardi and Alessi, 2012). Then, they compared the results. Accordingly, people who assess themselves as financially literate but actually have less objective literacy scores have been deemed as overconfident whereas those people who asssess themselves as less financially illiterate than they actually do have been called as underconfident ( p. 461). Thus, underconfidence not overconfidence is found to have a negative significant impact on net household wealth. Similarly, Robb and Woodyard (2011, p.66) has showed that both objective and subjective financial knowledge have significant influence on financial behavior together with other significant factors (e.g., income, financial satisfaction, education). Also, they emphasizes that knowledge is very important to financial decision and not sufficient and that other factors also have crucial roles on it.

Second, some research indeed employs overconfidence or better-than average scales in order to reveal its possible effect on mutual fund investments (Müller and Weber, 2010, p.130). This study shows that perceiving as being better than average increases the probability of active mutual fund ownership. They also concludes that better-than-average correlates with objective financial knowledge.

\section{Findings of Financial Literacy Studies}

\section{I. Determinants of Financial Literacy}

The studies on the determinants of financial literacy is abounding. In this frame, there is a great body of literature describing the role of demographics such as gender, education, experience, 
income, etc. on being financially literate (e.g., Guiso and Jappelli, 2008, pp. 1-36; Lusardi and Mitchell, 2008, pp. 1-10; Al-Tamimi and Bin Kalli, 2009, pp. 500-516; Ansong and Gyensare, 2012, pp. 126-133; Müller and Weber, 2010, pp. 126-153). More specifically, Chen and Volpe (1998, p.122) showed that low levels of financial literacy have been more seen amongst women, those with little work experience, those under age 30. Lusardi, Mitchell and Curto (2010, p. 367) provided evidence that women are less financially literate than men and also that cognitive ability and education could improve the literacy level. Additionally, men, those who work in banking and finance sector and those having both high income and educational level are more literate (Al-Tamimi and Bin Kalli, 2009, pp. 509-511). Yet, Ludlum et al. (2012, p. 29) stated that financial literacy has not varied according to gender while the presence of stock ownership, employment and maritual status has made a difference.

In a study (Guiso and Jappelli, 2008, p.17), it is also found that risk averse people more likely tended to have less financial knowledge while some studies reported that mother's education level made a difference in people's financial literacy level (Lusardi, Mitchell and Curto, 2010, p. 368; Ansong and Gyensare, 2012, p.131).

Lusardi and Mitchell (2008, pp. 1-10) concluded that financial literacy of women also diverges among age groups in that elder women tended more likely to have less financial literacy scores. In their previous study in 2007, it is also detected that white students and adults, compared to their black and hispanic peers, got higher financial literacy scores (Lusardi and Mitchell, 2007b, pp. 35-44).

As different determinants, Cole, Sampson, Zia (2011,pp. 1942-1944) provided evidence of that (higher) level of schooling and (greater) per capita expenditures are related with (higher) level of financial literacy. They also find that female headed rural households and nonfarm enterprise owned households display lower and higher financial literacy level respectively. Ansong and Gyensare (2012, p. 131) found no evidence that work location, access to media, father's education and level of study had an influence on financial literacy.

There may have three important points here. First, these studies on the determinants of financial literacy seem to have given researchers inspiration about which variables may be viewed as proxies for financial literacy. Resorting to these findings, some researchers employed some demographics for the sake of substituting for financial literacy while it has some disadvantages mentioned above.

Second, As Van Rooij, Lusardi and Alessi (Oct. 2007, p. 3) stated, divergency of financial literacy between demographics such as age, income gives policy makers or financial institutions a clue in that financial education could be more helpful when focused to these subgroups.

The last but not least, it has been suggested in some research (e.g. Van Rooij, Lusardi and Alessi, 2011, p.13; Van Rooij, Kool and Prast, 2007, p.720) that financial literacy may be endogenous variable. Here, it should be better for researchers to study on other explanatory variables beyond demographics such as age, income, experience, education, etc. which could predict the financial knowledge level of individuals. Thus, much effort has been devoted to unobservable variables 
which may explain financial literacy phenomenon above or beyond observable variables (e.g. demographics).

\subsection{Consequences of Financial Literacy}

A large body of literature has investigated how financial literacy of people would have a role on financial decision making or behavior. These valuable studies highlighted that financial literacy among individuals really made an impact on financial behavior. To exemplify, financial illiteracy has been considered as the reason for portfolio underdiversification (Guiso and Jappelli, 2008, pp. 1-36), inadequate stock participation (Van Rooij, Lusardi and Alessi, 2011, pp. 449472), unpreparedness for post-retirement times (Lusardi and Mitchell, 2007b, pp. 35-44), wealth accumulation (Van Rooij, Alessi and Lusardi, 2012, pp. 449-478), being unable to make personal contributions (Van Rooij, Kool, Prast, 2007, pp. 701-722; Dvorak and Hanley, 2010, pp. 645-652) and allocation changes (Dvorak and Hanley, 2010, 645-652) for retirement plans, poor investment decisions (Al-Tamimi and Bin Kalli, 2009, pp. 500-516), no intention to control personal budget (Sharahbani, 2012, pp. 156-163), financial dissatisfaction (Yoong, See and Baronovich, 2012, pp. 75-86), irresponsible financial management behavior (Perry and Morris, 2005, pp. 299313; Ludlum et al., 2012, pp. 25-33), poor financial practice behavior (Robb and Woodyard, 2011, pp. 60-70), irresponsible credit card usage of college students (Robb, 2011, pp. 690-698), inability to make informed financial decisions (Chen and Volpe, 1998, pp. 107-128), unimproved household financial management behavior (Hilgerth, Hogarth, and Beverly, 2003, pp. 309-322), preponderantly purchasing of actively managed funds in spite of their high expenses (Müller and Weber, 2010, pp. 126-153).

In a different context, financial literacy has been also found to have impact on evaluating financial reporting quality in auditing committees (McDaniel, Martin and Maines, 2002, pp. 139162). Another study (Kindle, 2010, pp. 470-481) concluded that social work students perceived financial literacy as relevant to their future social work practices. Especially, these students perceived that financial literacy related highly to poverty and welfare-to-work transitions.

Except a few studies, it can be seen that these studies heavily have concentrated on the role of financial literacy, as the name implies, on financial decision making or behavior. However articulated in different frames, it is rather apparent that this valuable research has striven for understanding financial behavior as a whole.

While aiming to explain financial decision making or behavior and finding strong evidence of the relationship between financial literacy and financial decision making or behavior, many studies have not provide a thorough and explicit explanation how this relation occurred. Accordingly, there exists little research explaining how financial literacy levels of people caused to financial behavior such as improved financial management, proper usage of credit cards, etc. although there has been a great body of literature establishing how much people are financially literate and which the financial literacy had the impact on any financial behavior. In this regard, Guiso and Jappelli (2008, p.17) provided evidence of financial literacy as a major variable in predicting the lack of portfolio diversification. They asserted that financially incapable people 
may underestimate the gains of portfolio diversification. Van Rooij, Lusardi and Alessie (2012, p. 472) detected a positive association between financial knowledge and retirement planning. In other words, financially literate people tended to plan for retirement periods. On the other hand, the authors have not suggested any argument over how people's financial literacy had influence on retirement planning. On the other hand, Van Rooij, Lusardi and Alessi (Oct. 2007, p. 25) found the relation of financial literacy to stock participation. In explaining the lack of stock ownership, they suggested that stocks are too complicated to grasp and that financial literate people could understand the operating the stock market.

In another study, Van rooij, Lusardi and Alessi (2011, p.3) suggested two connections in explaining the relationship between financial literacy and household wealth. First, financially literate people more likely opted for stock markets and these people had a tendency of making retirement planning. In these two ways, they could accumulated more wealth.

On the other hand, some studies (e.g. Hilgerth, Hogarth and Beverly, 2003, pp. 309-322) have referred that the researchers should conscientiously contemplate on the the nexus of causality. They examined the financial literacy's role on improved financial management behavior. They found that people whose scores is higher in terms of financial literacy tended to pursue recommended financial practices. But the authors stated that the direction of causality is unclear. Financial knowledge may increases as their savings or wealth increases or vice versa. Similarly, Dvorak and Hanley (2010, p. 650) detected a link between making more personal contributions and becoming more financially literate. They propounded that personal contributions by employees for their retirement plans have been motives for learning about both these plans and also options of these plans, hence making them more financially knowledgeable.

Most importantly, the prior research mainly regressing a rather complicated financial decision making or behavior on merely financial literacy phenomenon seems to have ignored other substantial factors which could quite likely influence this process. Does the solely financial literacy of individual helps his/her financial decision or behavior to be perfectly understood? Or, will the individual influence of financial literacy remain so strong after the inclusion of other notable but ignored factors into the specified research model? To be able to know this, researchers should design their research in a way that they should compare the relative impact of financial literacy to other predictor variables. Notwithstanding that understanding and using financial knowledge have an explicit impact on involved financial processes, we should remember that other behavioral or attitudinal factors may intervene in financial decision making or behavior as well as financial knowledge.

\section{Discussion}

Aiming to profoundly review of extant research, this study deduces various insights into financial literacy. Although its crucial importance on financial decision making or behavior has been manifested on vast quantity of studies, it seems that financial illiteracy as a prevailing issue around the world ranges from general groups to specific groups, from people in developed 
countries to those in developing ones. This contradiction calls for necessary steps which must be taken by policy makers who account for alleviating the inequalities and poverty and providing both financial and social welfare and by financial institutions which take mediating between fund lenders and fund borrowers as a chief mission.

Policy makers should take measures since financially illiterate people would probably confront problems in terms of the management on money, debt, investment. And this macroeconomically damages all society. Also, this issue has importance from the macroeconomic view (i.e., savings). Review of prior research shows that financial knowledge has an influence on retirement planning and hence wealth accumulation. Akerlof and Schiller (2010, pp. 147-162) in their Nobel prized book- Spiritus Animalis- mentions saving problem for the very reason. They argue that many people, on average, do not save enough and this could lead them to remain unprotected in their old age at that time they could make no more money and the consumption could exceed the income. We should note that they also emphasize the cultural differences as potential explanators of the savings divergency between countries. For example, Americans do not save- even negativecompared to China with the highest saving ratio of the world.

As mentioned above, financial institutions carry out a duty of mediating between people with excess funds and those who need funds. For this vital end to be efficiently achieved, all excess funds have to be incorporated into financial system without any worthy leakages while those people who need funds should be able to access to a wide range of these sources. Being able to know fundamental topics of this financial system highly matter to both counterparties. Excess funds here build a base for investments whereas fund needs could be satisfied in several means. Eventually, both investment and also borrowing alternatives constitute large product range of financial institutions. These institutions present lots of products tailored correctly to people's demands regarding income group, amount and maturity. Yet, the main point here is whether these two counterparties are able to choose. Put it differently, do these people have adequate financial knowledge in order to recognize and evaluate these wide range of products? Findings of extant literature answers this question to a large extent: People are found to be financially illiterate. Hence, financial institutions should pay sufficient attention to this issue. They should do that not only for mediating mission and also for their goals as a profit organizations since both these excess fund and fund demands represent a very critical component -demand for their products. For the sake of this two main goals, these institutions would shoulder the responsibility of alleviating financial illiteracy among people.

Financial illiteracy problem also reflects information asymmetry phenomenon which can be enormously seen at any bilateral relation. Let's say an individual investor at one side of the relation and a bank as a financial institution at the other side of this relation. Individual investors can be viewed as probable customers of financial institutions. These institutions have much elaborated knowledge about the riskiness and return capacity of their products whereas people with limited financial literacy do not know about those products. If they financially know more, they would save or invest in that particular product. Financial literacy of customers have crucial importance to these suppliers of financial products. 
In respect of theoretical implications, this review paper based on extant research reveals some notable insights into financial literacy phenomenon. First, the definitional issues should not have been ignored since a well structured definition represent the nucleus of the operationalization of an abstract concept in social sciences. Thus, the studies should primarily take care of describing financial literacy before they proceed to other stage of their research. Besides, researchers to replicate prior validated studies have a demanding problem since there is a lack of common financial literacy definition. Financial knowledge, financial sophistication, financial literacy, financial education have been used interchangeably.

Second, it is seen that financial literacy has been measured in several ways. Through some true-false questions, objective tests strives for the financial knowledge which an individual has in deed. Into these objective measures, researchers should add the option of "don't know" as being unable to know and misknowing should have been separately evaluated. Additionally, objective measures of financial literacy greatly vary in terms of the number of questions. Thus, these measures constitute a problem for replications studies. On the other hand, subjective financial literacy measures ask respondents what they think about their financial knowledge. Trying to learn the perceptions of their owned financial knowledge can make this resolution process more elaborate for researchers since overconfidence and underconfidence of participants may intervene in the oberved relationship. Expoliting proxies for financial literacy may include an important drawback since it is hard to dissociate the individual effect of proxy from the impact of financial literacy. Then, utilizing objective financial literacy measures in our studies seems more appropriate.

Third, although many research has argued the determinants of financial literacy, demographics have been the focus of these studies. Yet, financial literacy is suggested as a probable endogenous variable in some research. In this point, studies should concentrate on the other financial literacy predictors beyond demographics. Fourth, similarly to the previous one, many financial decisions are made under uncertainty, hence necessiating risk taking. Making a financial decision often goes beyond knowing and using financial issues. Herein, individuals' attitudes toward uncertainty, their tradeoffs between today and the future, their tolerance toward risk may have an important role on the financial decision making process. Therefore, risk averseness, time preferences as probable predictors of a financial decision should have been examined by the researchers.

Fifth, finding strong evidence of the relationship between two phenomenons may be very precious outcome in our studies yet accounting for this relationship or giving an explicit explanation of how this relationship has been occurred have more important role on the perfect comprehension of interested phenomenon. Accordingly, more effort should have been exerted by the researchers to explaining the relationship between financial literacy and any financial behavior (e.g. insufficient savings or investing).

Last, while prescribing an association between two phenomenons, researchers should ruminate about the direction of this proposed relation. In other words, the nexus of causality may go from one to another while you expect the opposite direction. For example, the finding that household total wealth increases by the financial literacy should have been questioned about 
which causes to another. It is also possible for financial literacy to beimproved by the increase of wealth.

In general, nonignorable effort has been exerted by the researchers to examining financial behavior by the financial literacy of people. Yet, regarding the prior research, some important points mentioned above have been identified. Based on a comprehensive review of prior studies, we aimed to reveal possible gaps amidst these valuable studies and to draw researchers' attention to several reflections of these gaps. Future research putting emphasis on financial literacy issue should primarily consider these points. 


\section{References}

AKERLOF, George.A., SHILLER, Robert J. (2010). Spiritus Animalis (N. Domanic \& L. Konyar, Trans.). İstanbul: Scala Yayıncilık.

AL-TAMIMI, Hussein A. Hassan, BIN KALLI, Al Anood (2009). Financial literacy and investment decisions of UAE investors, Journal of Risk Finance, Vol. 10, No. 5, pp. 500-516.

ANSONG, Abraham. \& GYENSARE, Michael Asiedu (2012). Determinants of university working-students' financial literacy at the University of Cape Coast, Ghana, International Journal of Business and Management, Vol. 7, No. 9, pp. 126-133.

ATKINSSON, Adele. and MESSY, Flore-Anne (212). Measuring financial literacy: Results of the OECD / International Network on Financial Education (INFE) Pilot Study, OECD Working Papers on Finance, Insurance and Private Pensions, No. 15, OECD Publishing. http://dx.doi.org/10.1787/5k9csfs90fr4-en

BAYER, Patrick J., BERNHEIM, B.Douglas, SCHOLZ, John Karl (1996). The effects of financial education in the workplace: evidence from a survey of employers, National Bureau of Economic Research, NBER Working Paper Series, Working Paper 5655, pp.1-29.

CHEN, Haiyang. and VOLPE, Ronald P. (1998). An analysis of personal financial literacy among college students, Financial Services Review, Vol. 7, Iss. 2, pp. 107-128.

COLE, Shawn, SAMPSON, Thomas, ZIA, Bilal. (2011). Prices or knowledge? What drives demand for financial services in emerging markets?, Journal of Finance, Vol. 66, No. 6, pp. 1933-1967.

DHAR, Ravi, ZHU, Ning (2006 May). Up close and personal: Investor sophistication and the disposition effect, Management Science, Vol. 52, No.5, pp. 726-740.

DIACON, Stephen (2004). Investment risk perceptions: Do consumers and advisers agree?, The International Journal of Bank Marketing, Vol. 22, No.3, pp. 180-198.

DVORAK, Tomas, HANLEY, Henry. (2010). Financial literacy and the design of retirement plans, Journal of Socio-Economics, Vol. 39, pp. 645-652.

GUISO, Luigi and JAPPELLI, Tullio. (2008). Financial literacy and protfolio diversification, European University Institute, Department of Economics, Working Paper ECO 2008/31, pp. 1-36.

HILGERTH, Marianne A., HOGARTH, Jeanne M., BEVERLY, Sondra G. (2003 July). Household financial management: The connection between knowledge and behavior, Federal Reserve Bulletin, Vol. 89, pp. 309-322.

HOWLETT, Elizabeth, KEES, Jeremy and KEMP, Elyria (2008). The role of self-regulation, future orientation, and financial knowledge in long-term financial decisions, Journal of Consumer Affairs, Vol. 42, No. 2, pp. 223-242.

HUSTON, Sandra J. (2010). Measuring Financial Literacy, Journal of Consumer Affairs, Vol. 44, No. 2, pp. 296-316.

KINDLE, Peter A. (2010). Student perceptions of financial literacy: Relevance to practice, Journal of Social Service Research, Vol. 36, No. 5, pp. 470-481.

LACHANCE, Marie-Eve, TANG, Ning (2012). Financial advice and trust, Financial Services Review, Vol. 21, pp. 209-226.

LUDLUM, Marty, TİLKER, Kris, RİTTER, David, COWART, Tammy, XU, Weichu, SMİTH, Brittany Christine (2012). Financial literacy and credit cards: A multi campus survey, International Journal of Business and Social Science, Vol. 3, No. 7, pp. 25-33.

LUSARDI, Annamaria, MITCHELL, Olivia S. (2007a). Baby boomer retirement security: the roles of planning, financial literacy, and housing wealth. Journal of Monetary Economics, Vol. 54, PP. 205224.

LUSARDI, Annamaria, MITCHELL, Olivia S. (2007b). Financial literacy and retirement preparedness: Evidence and implications for financial education, Business Economics, Vol.42, Iss.1, pp.35-44. 
LUSARDI, Annamaria, MITCHELL, Olivia S. (Oct.2006). Baby boomer retirement security: the roles of planning, financial literacy, and housing wealth. National Bureau of Economic Research, NBER Working Paper Series, Working Paper 12585, pp. 1-39.

LUSARDI, Annamaria, MITCHELL, Olivia S., and CURTO, Vilsa (2010). Financial literacy among the young, Journal of Consumer Affairs, Vol. 44, No. 2, pp. 358-380.

LUSARDI, Annamaria, MİTCHELL, Olivia S. (2008). Planning and financial literacy: How do women fare?, National Bureau of Economic Research, NBER Working Paper Series, Working Paper 13750, pp. 1-10.

MANDELL, Lewis., KLEIN, Linda Schmid (2009). The impact of financial literacy education on subsequent financial behavior, Journal of Financial Counseling and Planning, Vol. 20, Iss.1, pp. 15-24.

MCDANIEL, Linda, MARTIN, Rober D., MAINES, Laureen A. (2002). Evaluating financial reporting quality: The effects of financial expertise vs. financial literacy, The Accounting Review, Vol. 77, pp. 139-167.

MULLER, Sebastian, WEBER, Martin (2010 April). Financial literacy and mutual fund investments: Who buys actively managed funds?, Schmalenbach Business Review, Vol. 62, pp. 126-153.

PERRY, Vanessa G. and MORRIS, Marlene D. (2005). Who is in control? The role of self- perception, knowledge, and income in explaining consumer financial behavior, Journal of Consumer Affairs, Vol. 39, No. 2, pp. 299-313.

ROBB, Cliff A. (2011). Financial knowledge and credit card behavior of college students, Journal of Family and Economic Issues, Vol. 32, pp. 690-698.

ROBB, Cliff A., WOODYARD, Ann S. (2011). Financial knowledge and best practice behavior, Journal of Financial Counseling and Planning, Vol. 22, Iss.1, pp. 60-70.

SERVON, Lisa J., KAESTNER, Robert (2008). Consumer financial literacy and the impact of online banking on the financial behavior of lower-income bank customers, Journal of Consumer Affairs, Vol. 42, No. 2, pp. 271-305.

SHAHRABANI, Shosh. (2012.) The effect of financial literacy and emotions on intent to control personal budget: a study among israeli college students, International Journal of Economic Finance, Vol. 4, No.9, pp. 156-163.

SMİTH, Hyrum, FINNE, Michael S., and HUSTON, Sandra J. (2011). The impact of financial sophistication on adjustable rate mortgage ownership, Journal of Financial Counseling and Planning, Vol. 22, Iss. 2, pp.3-15.

VAN ROOIJ, Maarten, LUSARDI, Annamaria., ALESSI, Rob. (2011). Financial literacy and stock market participation, Journal of Financial Economics, Vol. 101, pp. 449-472.

VAN ROOIJ, Maarten, LUSARDI, Annamaria., ALESSI, Rob. (2011). Financial literacy, retirement planning and household wealth, National Bureau of Economic Research, Working Paper 17339, pp. 1-40.

VAN ROOIJ, Maarten., LUSARDI, Annamaria, ALESSI, Rob. (2012). Financial literacy, retirement planning and household wealth, Economic Journal, Vol. 122 (May), pp.449-478.

VAN ROOIJ, Maarten., KOOL, Clemens J.M., PRAST, Henriette M. (2007). Risk-return preferences in the pension domain: Are people able to choose?, Journal of Public Economics, Vol. 91, pp. 701-722.

VAN ROOIJ, Maarten., LUSARDİ, Annamaria, ALESSİ, Rob. (October 2007). Financial literacy and stock market participation, National Bureau of Economic Research, Working Paper 13565, pp.1-46.

VASS, Jeff (2012). The case of cross-generational couples' problem-solving the life course, International Journal of Business and Social Science, Vol. 3, No. 14, pp.166-175.

WACHIRA, Mwangi Isaac, KIHIU, Evelyne N. (2012). Impact of financial literacy on access to financial services in Kenya, International Journal of Business and Social Science, Vol. 3, No. 19, pp. 42-50.

WANG, Mei, KELLER, Carmen \& SIEGRIST, Michael (2011). The less you know, the more you are afraid of-A survey on risk perceptions of investment products, Journal of Behavioral Finance, Vol. 12, Iss. 1, pp. 9-19.

YOONG, Folk Jee, SEE, Beh Loo, BARONOVICH Diana-Lea (2012). Financial literacy key to retirement planning in Malaysia, Journal of Management and Sustainability, Vol. 2, No. 1, pp.75-86. 
